\title{
Assessing Organizational Behavior: A Case Study in a Colombian Retail Store
}

\author{
Odette CHAMS-ANTURI ${ }^{1}$, Anamaria P. GOMEZ ${ }^{2}$; Juan P. ESCORCIA-CABALLERO ${ }^{3}$ \\ and Milton SOTO-FERRARI ${ }^{4}$ \\ ${ }^{1}$ Department of Management. Universidad de la Costa. Barranquilla, Colombia \\ ${ }^{2}$ Department of Educational Leadership, Research and Technology \\ Western Michigan University. Kalamazoo, MI 49008, USA
}

${ }^{3}$ Department of Entrepreneurship and Management. Universidad del Norte. Barranquilla, Colombia

${ }^{4}$ Marketing and Operations Department. Indiana State University. Terre Haute IN 47807, USA

Correspondence should be addressed to: Odette CHAMS-ANTURI; ochams@cuc.edu.co

Received date: 4 Mars 2020; Accepted date: 28 May 2020; Published date: 24 July 2020

Academic Editor: Mario César Dávila Aguirre

Copyright (C) 2020. Odette CHAMS-ANTURI, Anamaria P. GOMEZ; Juan P. ESCORCIA-CABALLERO and Milton SOTO-FERRARI. Distributed under Creative Commons Attribution 4.0 International CC-BY 4.0

\begin{abstract}
In this research, significant components of organizational behavior in an actual commercial retail store located in Colombia, were further considered and investigated. The business case was analyzed by applying a structured questionnaire in the company. It was concluded that the success of the company is influenced by factors such as motivation, job satisfaction, emotions and decision making, indicating that perception factors and attitudes need reinforcement. In addition, recommendations for the intervention of organizational behavior, as well as the perspective of reducing the negative impacts that these findings might have on the obtained results are also proposed.
\end{abstract}

Keywords: Organizational Behavior, Human Behavior, Psychological Factors.

\section{Introduction}

Organizational behavior (OB) theory researches the effect of the human behavior within an organizational environment, focusing on improving the organizational effectiveness by reducing behaviors such as absenteeism and staff turnover (Robbins and Judge, 2013; Organ, 2018), which negatively affects the organizational performance. OB theory is a multi-faceted discipline with a major contribution from behavioral sciences and evidence-based practices. OB uses the measurement and analysis of human behaviors to maximize employees' productivity and maximize the

Cite this Article as: Odette CHAMS-ANTURI, Anamaria P. GOMEZ; Juan P. ESCORCIA-CABALLERO and Milton SOTO-FERRARI (2020)," Assessing Organizational Behavior: A Case Study in a Colombian Retail Store ", IBIMA Business Review, Vol. 2020 (2020), Article ID 261423, DOI: 10.5171/2020.261423 
performance of human resources development and the management of organizational systems (Luthans, 2011; Chams-Anturi, Moreno-Luzon and EscorciaCaballero, 2019; Pangil and Nasurdin, 2019).

The application of OB theory using systematic methodologies results in a more accurate prediction than those based on intuition, which is necessary to generate management solutions adjusted to each organizational need, instead of general solutions (Griffin and Moorhead, 2011; Robbins and Judge, 2013). Therefore, OB has become a critical aspect for the organizational success if properly applied within the organization (Bateman and Crant, 1999).

The study of OB provides managers with challenges that can be considered as opportunities for business growth. It can improve employees' productivity, as it teaches managers how to treat their staff and understand how to implement change programs. Also, it helps employees balance between work and their lives (Robbins and Judge, 2013; Wagner and Hollenbeck, 2014; Mullins and Mclean, 2019). In addition, OB offers managers a useful guide to create a healthy work environment by stimulating the innovation of their employees.

The purpose of this research is to study a current organizational behavior case of an actual retail store located in Colombia, highlighting the theoretical foundations of the organizational behavioral research, measuring and analyzing the behavior of the individuals while facing changes in the environment, and defining practical implications for the entrepreneurs.

\section{Theoretical Framework}

Organizational behavior $(\mathrm{OB})$ is defined as the field of study that investigates the behavior of individuals within an organization, aiming to learn about their perceptions, values and cognitive capacity in working environments (Davis and Newstrom, 2002; Chiavenato, 2009; Robbins and Judge, 2013; Mcshane, 2018; Mullins and Mclean, 2019). Chiavenato
(2009) states that OB distinguishes an organization from another, even in the same economic sector. Also, he states that each person is subject to different influences, both external and internal, that affect his behavior individually and consequently his interaction with other people in the organization. Psychological constructs such as attitudes, motivations, job satisfaction, perceptions, emotions and decision making are popular ways to describe and analyze what goes into OB (Heath and Sitkin, 2001; Miner, 2003). A brief description of each construct is presented as follows.

Attitudes are statements of favorable or unfavorable evaluations of objects, people or events. They reflect how a person feels about something. Attitudes are mainly composed of three components: cognition, affection and behavior (Breckler, 1984). The cognitive component of an attitude describes the belief of how a person sees things, for example, "my boss is unfair". The affective component is based on the emotional part of an attitude, for example, "I dislike my boss". Moreover, the behavior component of an attitude refers to a person's intention to behave in a certain way towards someone or something, for example, "I will look for another job, because my boss does not listen to me". These components are closely related, which denote a negative attitude towards the boss.

An individual has many attitudes, but regarding organizational behavior, the number of attitudes at work is limited, these are positive or negative evaluations that employees have about various aspects of their work environment (Moreno-Luzon, Chams-Anturi and Escorcia-Caballero, 2018). Organizational behavior researchers have focused on three attitudes: work involvement, job satisfaction and organizational commitment (Brooke, Russell and Price, 1988). Other attitudes considered by researchers are organizational support and dedication of employees.

Job satisfaction is defined as the positive feeling resulting from a personal work accomplishment (Robbins and Judge, 2013). 
Enjoying work highly correlates with high levels of satisfaction. Jobs that generate and provide their employees with training and independence satisfy most workers (Barling, Kelloway and Iverson, 2003). Employees prefer stimulating jobs that pose challenges versus predictable and routine ones. Evidence also indicates that employees who are satisfied with their jobs increase customer satisfaction and loyalty (Schneider and Bowen, 1985). Satisfied workers are more friendly, optimistic and responsible, and also less likely to change their jobs, these are advantages appreciated by the client who will ultimately receive a better service (Bitner, Booms and Mohr, 1994).

Motivation affects the intensity, direction and persistence of the effort exerted by a person to achieve a goal. Intensity refers to the energy applied by a person in reacting to events, which requires direction to get favorable results. Persistence is the time through which the individual maintains the effort. People who are motivated focus on their tasks until their goal is achieved (Robbins and Judge, 2013; Pinder, 2014).

In the 50s, several concepts on motivation were developed and four specific theories were formulated. (1) Theory of the hierarchy of needs, by Abraham Maslow, who raised the idea that each person has a hierarchy of five needs: physiological, safety, social, esteem and self-realization (Maslow, 1954). (2) Theories X and Y, by Douglas McGregor, who proposed two visions of human beings: A negative or $\mathrm{X}$ vision where the employee dislikes his work and must be directed, and another positive or $Y$ vision where the employee likes his job and is self-responsible for it (McGregor, 1960). (3) McClelland's theory of needs, by David McClelland, focuses on three needs: achievement (based on the urge to excel and fighting for triumph), power (based on the need to make others behave according to a specific way) and affiliation (the desire to have friendly and close relationships) (McClelland, 1961). (4) The theory of the two factors or the theory of motivation and hygiene, by Frederik Herzberg, who states that the individual-work relationship and the attitude adopted to meet any work challenge, are fundamental to determine the success or failure of the job (Herzberg, Mausner and Snyderman, 1959). Although these theories are widely known, there are several arguments regarding their validity. Recently, OB researchers have developed new contemporary theories of motivation, such as (5) The theory of cognitive evaluation, which introduces extrinsic awards for doing work that previously had intrinsic rewards (De Charms, 1968). (6) The theory of goal setting, which states the importance of establishing goals to increase performance (Tubbs, 1986). (7) The theory of personal effectiveness, or social cognitive theory or social learning theory, which refers to a person's belief in carrying out a task (Bandura, 1997). (8) The theory of reinforcement, which states the importance of reinforcement to get a desired behavior (Komaki, Coombs and Schepman, 1996). (9) The theory of equity, which encourages people to compare their work results (Ronen, 1986). (10) The theory of expectations states that a good evaluation of the employee's performance will lead to a better performance, requiring organizational awards, such as salary bonuses (Robbins and Judge, 2013).

Perception is the process in which people interpret the impressions they have about a situation to get a meaning of what happens in the environment. There are some factors that can distort the perception of people such as the recipient (e.g., motives and expectations), the object (e.g., news) and the situation (e.g., time) in which the perception unfolds. There are also some valuable simplifications that allow subjects to get a quick and accurate perception (Robbins and Judge, 2013): (1) Selective perception: Which is useful when we highlight some stimuli to assimilate everything we see. This characteristic highlights a person, object or event to what is perceived. (2) Halo effect: Which is when an impression of a person is outlined based on a characteristic such as appearance. (3) Contrast effect: When evaluating and comparing characteristics of people. In addition, (4) Stereotyping: Where someone is judged based on the perception of the group to which he/she belongs. 
Emotions are defined as those direct feelings toward someone (Fridja, 1993) and they are usually transitory. Some examples of emotions are anger, fear, sadness, happiness and surprise, accompanied by facial expressions and caused by specific events (Ashkanasy, Hartel and Daus, 2004). The founder of modern philosophy, René Descartes, identified six primitive passions astonishment, love, hate, desire, joy and sadness - arguing that they compose all other emotions (Descartes, 1989). Charles Darwin took a broader approach, which suggested that emotions developed to help solve problems. Emotions motivated people to take actions to survive.

Decision-making occurs when an individual chooses between two or more alternatives. There are different ways to decide. (1) The rational model occurs when choices are made by maximizing value within constraints (Simon, 1986). These choices follow a method by first defining a problem, identifying the decision criteria, weighting the criteria, developing and testing alternatives, and finally selecting the best alternative. Several assumptions support this model, including that all information is available in order to choose a good alternative (March, 1994). (2) Bounded rationality, where the individual responds to the problem by reducing it to a level easier to understand (Kahneman, 2003); and (3) intuition, which is an unconscious process formed from experience. The latter is considered to be the least rational of the options, but it is the most usually chosen. (Gilovich, Griffin and Kahnemann, 2002).

Before starting with the decision-making procedure, it is important to know how to reduce biases and errors. Focusing on the goals facilitates the elimination of options that contradict interests, nullifies excess of confidence, does not give meanings to random eventualities and increases decision alternatives by developing a wide range of different elections.

\section{Research Methodology}

The organizational behavior is analyzed using a case study in the import business unit at one of the largest retail chains in Colombia. Molyntix is a company with approximately 70 years in the retail market, with $100 \%$ national capital and an approximate market share of 22 percent. Molyntix has more than 400 stores across the national territory and it is recognized as the leading company in the commercialization of optimal quality consumer products. The company markets a wide portfolio of private and store-brand products in several categories: grocery, textiles, toys, sports, home appliances, technology and others.

To obtain the information, a structured questionnaire of 44 questions was carried out following the method proposed by Robbins and Judge (2013). All items were measured using a Likert scale with values ranging from 1 (totally disagree) to 5 (totally agree). The questionnaire was applied to the Molyntix interest group, which included commercial directors of each category, customs agency, international cargo agent and operators. The total population is equal to 65 participants. In order to calculate a proper sample size, the following calculation was used:

$$
n=\frac{Z^{2} * \mathrm{~N} * \mathrm{p} * \mathrm{q}}{e^{2} *(N-1)+Z^{2} * p * q}
$$

Where:

$\mathrm{n}$ : sample size

$\mathrm{Z}$ : degree of confidence

$\mathrm{N}$ : population

p: probability of success

q: probability of failure

e: estimation error

Replacing values; 


$$
\begin{gathered}
n=\frac{0.95^{2} * 65 * 0.5 * 0.5}{0.03^{2} *(65-1)+0.95^{2} * 0.5 * 0.5} \\
n=52 \text { participants }
\end{gathered}
$$

Then, the study was carried out on $80 \%$ of the total population (i.e., $n=52$ ). The observation of the individuals and their specific behavior within the organization prevailed. Therefore, the content analysis and participants' observation are considered as a key part of the process.

The research was based on the six basic principles of qualitative validity (Robbins and Judge, 2013), considering the following:

- Credibility or internal validity: Where different methods were combined such as the observation of the process, questionnaires and analysis of written documents. In addition, the research was carried out by a personnel that is not part of the area under investigation, which reduces biases and guarantees the credibility of the study.

- Transferability or external validity: Although the results of the present investigation are not extrapolated to other organizations, the methodological experience can be applied to other commercial establishments.

- Reliability: Where the studies developed with respect to the object of analysis were taken into account.

- Confirmation: This investigation was configured by the triangulation of methods, analysis of document content, observation and surveys. The data collected are analyzed by the researchers; which guarantees the objectivity of the research.

- Integrity: Where the identification of informants is reserved, maintaining relationships of trust with them.
- Consistency: Where the research seeks to respond to a need evidenced by researchers in one of the most important commercial chains in the country, in order to provide a solution to the problem described.

\section{Results}

Individual factors were measured to study the organizational behavior of Molyntix using a survey questionnaire for the 52 participants. The results are as follows:

\section{Demographic Information}

From the 52 responses obtained, the following information was obtained:

1. $44 \%$ belong to the senior management, $37 \%$ to the middle managers and $19 \%$ to the professional and operational staff.

2. $44 \%$ of the respondents are female and $56 \%$ are male. The average age is approximately 38 years old.

3. $88 \%$ of the respondents have a professional training in the postgraduate modality, which shows a high level of skills in specific areas within the process.

4. On average, the personnel surveyed are more than 3 years old in Molyntix. All of them know the strategy of the organization at each corresponding level.

\section{Analysis of Results}

Below are the results obtained for each of the factors - attitudes, motivations, job satisfaction, perceptions, emotions and decision making of Molyntix, accompanied by a behavioral analysis or a diagnostic 
description and a series of recommendations for each one.

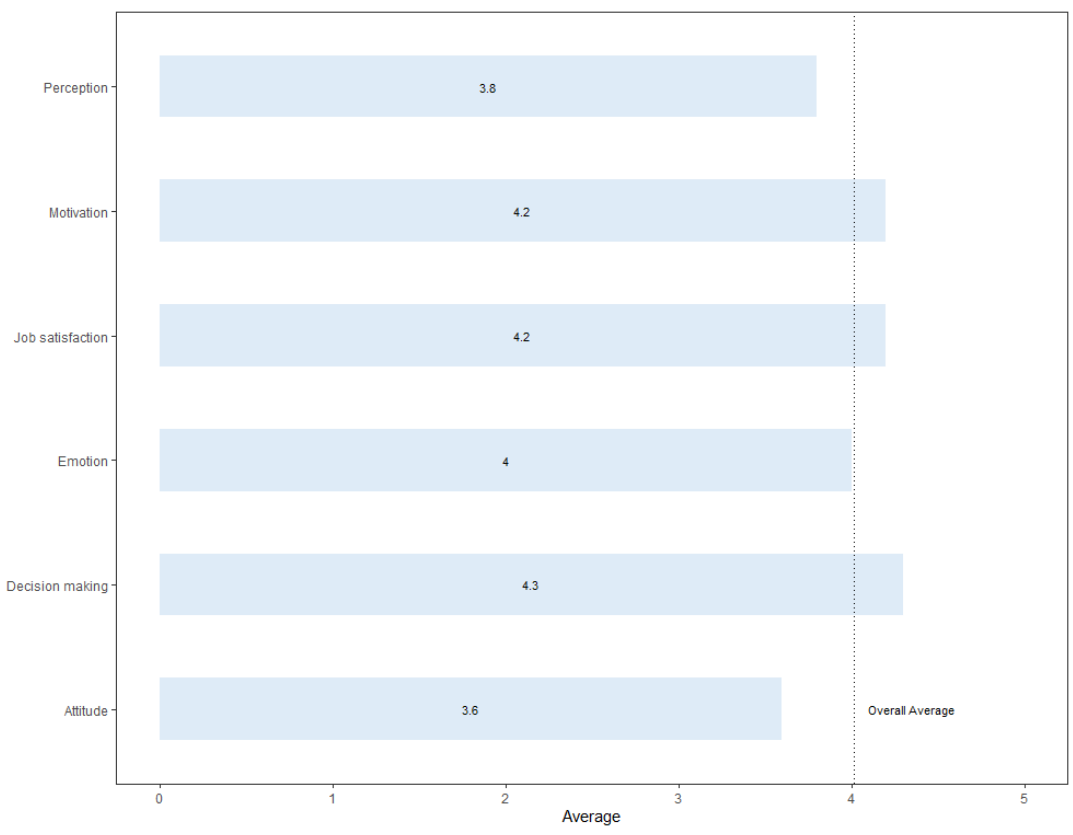

Figure 1: Survey results

\section{Attitudes}

The results show that the individuals in the business process of the company are not completely satisfied with their assigned work and their involvement in the organizational decisions. Results show low levels of organizational commitment and a perception of low organizational support and recognition.

Table 1: Attitude

\begin{tabular}{|c|l|l|l|}
\hline AVERAGE & \multicolumn{1}{|c|}{ FINDINGS } & PROPOSALS FOR IMPROVEMENT \\
\hline \multirow{5}{*}{3} & $\checkmark \quad$ It is considered that & $\checkmark$ & Create safe spaces for \\
interaction with employees to forge \\
immediate bosses and co-workers are \\
friendly, organized and flexible. \\
$\checkmark \quad$ No significant features of \\
irony or injustice are denoted. \\
$\checkmark \quad$ Attempts to adapt to new \\
team situations are evident. \\
$\checkmark \quad$ The staff is considered \\
employees in the changes that affect \\
important for Molyntix, and they are \\
committed to the quality of their work. \\
$\checkmark \quad$ Sometimes employees feel \\
that their boss is unfair.
\end{tabular}




\section{Motivation}

The individuals involved in the business process in Molyntix show a good level of motivation which involves intensity, direction and persistence of the individual's effort towards achieving a goal.

Table 2: Motivation

\begin{tabular}{|c|c|c|}
\hline AVERAGE & FINDINGS & PROPOSALS FOR IMPROVEMENT \\
\hline 4,2 & $\begin{array}{l}\checkmark \\
\text { leaders are aware of their skills. } \\
\checkmark \quad \text { They also consider that their } \\
\text { cognitive capacity has increased as an } \\
\text { effect of the training processes received } \\
\text { at Molyntix. } \\
\checkmark \quad \text { Staff can ask questions and } \\
\text { suggest modifications to the traditional } \\
\text { ways of doing things without any fear. } \\
\checkmark \quad \text { There is a feeling of } \\
\text { commitment, but sometimes the staff } \\
\text { does not feel aligned with the direction } \\
\text { of Molyntix. } \\
\checkmark \quad \text { Recognitions and incentives } \\
\text { are received for their actions, exalting } \\
\text { their growth in Molyntix. } \\
\checkmark \quad \text { Workers do not feel heard at } \\
\text { all, but this gap is compensated with the } \\
\text { training process, a respectful work } \\
\text { environment and remuneration } \\
\text { according to their profiles. }\end{array}$ & $\begin{array}{l}\checkmark \quad \text { Creating spaces to improve } \\
\text { the organizational communication in } \\
\text { which workers can express their } \\
\text { feelings and meet their social needs. }\end{array}$ \\
\hline
\end{tabular}

\section{Job Satisfaction}

This factor involves several elements such as activities, compliance with internal labor regulations, relationship with managers and colleagues, and performance criteria. This sample does not illustrate absenteeism or employee turnover.
The results show a good level of job satisfaction among the employees of Molyntix. The employees are satisfied and speak positively about the organization, help each other, exceed the expectations of their job and strive beyond their duty 
Table 3: Job satisfaction

\begin{tabular}{|c|c|c|}
\hline AVERAGE & FINDINGS & PROPOSALS FOR IMPROVEMENT \\
\hline 4,2 & $\begin{array}{l}\checkmark \\
\checkmark \text { Employees are interested in the } \\
\text { well-being of their colleagues. } \\
\checkmark \quad \text { The leader of the process } \\
\text { effectively directs his subordinates and } \\
\text { gives them confidence in their work. } \\
\checkmark \quad \text { Workers share that wages are } \\
\text { proportional to what other companies } \\
\text { offer. } \\
\checkmark \\
\text { feel their support and consider that they } \\
\text { are properly directed. } \\
\checkmark \\
\text { current work and have confidence to } \\
\text { discuss doubts and concerns, and ask for } \\
\text { cooperation from their peers. } \\
\checkmark \quad \text { They believe that work is a good } \\
\text { opportunity to grow and improve. } \\
\checkmark \\
\text { their job require improvement. }\end{array}$ & $\begin{array}{l}\checkmark \quad \text { Create interactive spaces } \\
\text { between work teams to encourage a } \\
\text { more effective communication. } \\
\checkmark \quad \text { Design a formal mechanism } \\
\text { for the evaluation of job satisfaction, } \\
\text { considering alert indicators that allow } \\
\text { constant monitoring of this variable. }\end{array}$ \\
\hline
\end{tabular}

\section{Perception}

The perception factor shows that the personnel involved in the business process in Molyntix does not correctly perceive and interpret the different situations presented at work.

Table 4: Perception

\begin{tabular}{|c|c|c|}
\hline AVERAGE & FINDINGS & PROPOSALS FOR IMPROVEMENT \\
\hline 3,8 & $\begin{array}{l}\checkmark \\
\text { The work area is adequate to } \\
\text { perform daily functions. } \\
\checkmark \quad \text { The workplace induction } \\
\text { process is clear and adequate. Team } \\
\text { work is encouraged at all stages. } \\
\checkmark \quad \text { Leaders avoid rumors to arise. } \\
\checkmark \quad \text { It is difficult for the group to } \\
\text { work with people with weak work } \\
\text { habits. } \\
\checkmark \\
\text { work contributes to the institutional } \\
\text { objectives. }\end{array}$ & $\begin{array}{l}\checkmark \text { A performance evaluation } \\
\text { system is suggested. A critical factor } \\
\text { to evaluate is the impact generated by } \\
\text { the achievements of workers on } \\
\text { meeting the objectives of Molyntix. } \\
\checkmark \quad \text { It is suggested to work on } \\
\text { skills, such as resilience, at the } \\
\text { workplace to minimize unwanted } \\
\text { behaviors among the employees } \\
\text { while a new process is implemented. }\end{array}$ \\
\hline
\end{tabular}

\section{Emotions}

Emotions at Molyntix are properly shown among the employees. 
Table 5: Emotions

\begin{tabular}{|c|c|c|}
\hline AVERAGE & FINDINGS & PROPOSALS FOR IMPROVEMENT \\
\hline 4,0 & $\begin{array}{l}\checkmark \quad \text { Employees are constantly } \\
\text { encouraged to improve their cognitive } \\
\text { capacity and skills. } \\
\checkmark \quad \text { Employees consider that } \\
\text { Molyntix has played an important role in } \\
\text { their lives and they feel proud to belong } \\
\text { to it. } \\
\checkmark \\
\text { management of their emotions. } \\
\checkmark \text { Open communication channels } \\
\text { are present. } \\
\checkmark \\
\text { their fears, or clearly demonstrate their } \\
\text { joys and feelings. } \\
\checkmark \text { The employees are comfortable } \\
\text { receiving compliments. }\end{array}$ & $\begin{array}{l}\checkmark \text { Promote the participation of } \\
\text { employees in the planning of } \\
\text { organizational changes. } \\
\checkmark \quad \text { Create interactive spaces } \\
\text { between work teams, to encourage a } \\
\text { more effective communication. }\end{array}$ \\
\hline
\end{tabular}

\section{Decision-Making}

The results show that employees in Molyntix are skillful in decision making. They are good at analyzing the situation, staying bias alert, combining rational analysis with intuition and maintaining high levels of creativity.

Table 6: Decision-making

\begin{tabular}{|c|c|c|}
\hline AVERAGE & FINDINGS & PROPOSALS FOR IMPROVEMENTS \\
\hline 4,3 & $\begin{array}{l}\checkmark \\
\text { Employees feel supported by } \\
\text { their bosses. } \\
\checkmark \quad \text { Problems are analyzed and } \\
\text { solutions' alternatives are identified, } \\
\text { verifying the possible risks and benefits. } \\
\checkmark \text { Creativity is a factor that helps } \\
\text { generate solutions, and participants feel } \\
\text { responsible for them. } \\
\checkmark \text { Time and organizational } \\
\text { alignment are obstacles in their } \\
\text { performance. }\end{array}$ & $\begin{array}{l}\checkmark \text { A performance evaluation } \\
\text { system is suggested. A critical factor } \\
\text { to evaluate is the impact generated } \\
\text { by the achievements of workers on } \\
\text { meeting the objectives of Molyntix. } \\
\checkmark \quad \text { It is suggested to work on } \\
\text { skills, such as resilience, at the } \\
\text { workplace to minimize unwanted } \\
\text { behaviors among the employees } \\
\text { while the new process is } \\
\text { implemented. }\end{array}$ \\
\hline
\end{tabular}

\section{Conclusions}

According to the results, the success of Molyntix business process is influenced by favorable characteristics of organizational behavior such as motivation, job satisfaction, emotions and decision-making, in contrast to the characteristics of perceptions and attitudes, which require a prompt intervention from the company to reduce their negative impact on current and future projects. Then, some 
recommendations for intervention are as follows:

- Designing a communication plan for all the organization levels for a better implementation of current and future projects.

- Creating safe spaces for communication to promote integration, personal and professional development, and employees' recognition, in order to generate favorable changes in the organizational behavior of workers involved in the process.

- Implementing positive reinforcement motivation strategies. This reinforcement must be supported by specific achievements, which must be previously arranged and communicated. This should also be aligned with the goals of the organization. Productivity results can be also considered.

- Designing and implementing strategies for controlling emotions, especially in those employees who have the responsibility to negotiate with external suppliers and internal clients. An important aspect for a successful performance of a process corresponds to the purchase price of the products imported and the management of the inventory.

- Considering that the information generated by the process is shared, it is necessary to reconcile the entire structure to favor and potentiate these advantages. Improving communication streams into the organizational levels. Establishing interdisciplinary teams to make strategic decisions that would facilitate measuring the performance with the suggested motivation strategy.

The authors of this paper believe that the described intervention recommendations will generate positive results into the organizational behavior for Molyntix that will effectively contribute to a higher level of productivity in the company.

\section{Acknowledgement}

The authors of this paper would like to express their gratitude to all the company employees who participated in this investigation. The name Molyntix is a reference designation as the company name has been concealed due to a disclosure agreement.

\section{References}

- Ashkanasy, N., Hartel, C. and Daus, C. (2004) 'Diversity and emotion: The new frontiers in organizational behavior research', Journal of Management, 28(3), 307-338.

- Bandura, A. (1997) Self-efficacy: The exercise of control, Freeman, New York.

- Barling, J., Kelloway, E. and Iverson, R. (2003) 'High-quality work, job satisfaction, and occupational injuries', Journal of Applied Psychology, 88(2), 276.

- Bateman, T. and Crant, J. (1999) 'Proactive behavior: Meaning, impact, recommendations', Business Horizons, 42(3), 63-70.

- Bitner, M., Booms, B. and Mohr, L. (1994) 'Critical service encounters: The employee's viewpoint', Journal of Marketing, 58(4), 95-106.

- Breckler, S. (1984) 'Empirical validation of affect, behavior, and cognition as distinct components of attitude', Journal of Personality and Social Psychology, 47(6), 1191.

- Brooke, P., Russell, D. and Price, J. (1988) 'Discriminant validation of measures of job satisfaction, job involveAent, and organizational commitment', Journal of Applied Psychology, 73(2), 139.

- Chams-Anturi, O., Moreno-Luzon, M. D. and Escorcia-Caballero, J. P. (2019) 'Linking organizational trust and performance through ambidexterity', 
Personnel Review.

- De Charms, R. (1968) Personal causation: The internal affective determinants of behavior, Academic Press, New York.

- Chiavenato, I. (2009) Comportamiento 0rganizacional. La dinámica del éxito en las organizaciones, 2da. ed.,Mc Graw Hill,México.

- Davis, K. and Newstrom, J. (2002) Human behavior at work: Organizational behavior, 11thed.,McGraw-Hill, New York.

- Descartes, R. (1989) The passions of the soul, Hackett, Indianapolis.

- Fridja, N. (1993) Moods, emotion episodes and emotions, In M. Lewis y J. Haviland (eds.), Handbook of Emotions. Nueva York: Guilford Press, 381-403.

- Gilovich, V., Griffin, D. and Kahnemann, D. (2002) Heuristics and biases: The psychology of intuitive judgement, Cambridge University Press, Nueva York.

- Griffin, R. and Moorhead, G. (2011) Organizational behavior: Managing people and organizations, 9th ed., Nelson Education, Canada.

- Heath, C. and Sitkin, S. (2001) 'Big-B versus Big-0: What is organizational about organizational behavior?', Journal of Organizational Behavior: The International Journal of Industrial, Occupational and Organizational Psychology and Behavior, 22(1), 43-58.

- Herzberg, F., Mausner, B. and Snyderman, B. (1959) The motivation to work, Wiley, Nueva York.

- $\quad$ Kahneman, D. (2003) 'Maps of bounded rationality: Psychology for behavioral economics', American Economic Review, 93(5), 1449-1475.

- Komaki, J., Coombs, T. and Schepman, S.
(1996) Motivational implications of reinforcement theory, In R. Steers, L. Porter, y G. Bigley (eds.), Motivation and Work Behavior, 6th ed. Nueva York: McGraw-Hill, 87-107.

- Luthans, F. (2011) Organizational behavior: An evidence-based approach, 12th ed., McGraw-Hill, New York.

- March, J. (1994) A primer on decision making, The Free Press, Nueva York.

- Maslow, A. (1954) Motivation and Personality,Harper \& Row, Nueva York.

- McClelland, D. (1961) The achieving society,Van Nostrand Reinhold, Nueva York.

- McGregor, D. (1960) The human side of enterprise, McGraw-Hill, Nueva York.

- Mcshane, S. (2018) Organisational behavior, 6th ed., McGraw-Hill, Irwin.

- Miner, J. (2003) 'The rated importance, scientific validity, and practical usefulness of organizational behavior theories: A quantitative review', Academy of Management Learning \& Education, 2(3), 250-268.

- $\quad$ Moreno-Luzon, M. D., Chams-Anturi, O. and Escorcia-Caballero, J. (2018) Organizational legitimacy and stakeholder trust in the organization: A feed-forward relationship, In Díez-deCastro, E; Peris-Ortiz, M. (eds). Organizational legitimacy. Springer, Cham, 283-299.

- Mullins, L. and Mclean, J. (2019) Organisational behavior in the workplace,Pearson Education Limited, New York.

- Organ, D. (2018) 'Organizational citizenship behavior: Recent trends and developments', Annual Review of Organizational Psychology and Organizational Behavior, 80, 295-306.

- Pangil, F. and Nasurdin, A. (2019) 
'Assessing the relationship between organisational commitment and knowledge sharing behavior', Malaysian Management Journal, 13, 3550.

- Pinder, C. (2014) Work motivation in organizational behavior, 2nd ed., Psychology Press, New York.

- Robbins, S. and Judge, T. (2013) Organisational behavior, 15th ed., Editorial Pearson,Boston.

- $\quad$ Ronen, S. (1986) 'Equity perception in multiple comparisons: A field study', Human Relations, 39(4), 333-345.

- Schneider, B. and Bowen, D. (1985)
'Employee and customer perceptions of service in banks: Replication and extension', Journal of Applied Psychology, 70(3), 423.

- Simon, H. (1986) 'Rationality in psychology and economics', Journal of Business, S209-S224.

- Tubbs, M. (1986) 'Goal setting: A metaanalytic examination of the empirical evidence', Journal of Applied Psychology, 71(3), 474.

- Wagner, J. and Hollenbeck, J. (2014) Organizational behavior: Securing competitive advantage, 2nd ed., Routledge, New York \& London. 